\title{
ESTABLISHING OF THE MONO- AND POLYINVASION IM- PACT ON SOME MORPHO-FUNCTIONAL INDICES IN WILD BOARS
}

\author{
Ştefan Rusu
}

Institute of Zoology, Chisinau, Republic of Moldova, e-mail: rusus1974@yahoo.com

\begin{abstract}
In the paper is described the mono- and poly-invasions impact on some morpho-functional indices in wild boars. So, in result of the investigation of hematological indices in uninfested mono- and poly-parasitized wild boars, it was established that both the indices of hemoglobin content, of hematocrit, erythrocyte's number, thrombosis time and ESR (erythrocyte sedimentation rate) vary and are more increased in the I group with uninfested wild boars compared to mono - and poly-parasitized ones. It has been established that at infested boars with S. papillosus from the I group, and in those infested with D. lanceolatum from the II group there is a decrease of hemostatic indices, but their maximum decrease is highlighted in the IV group with wild boars infested with Dicrocoelium lanceolatum, Strongyloides papillosus, Metastrongylus elongatus and Eimeria debliecki. This decrease is due to eliminated exotoxins by parasites, which contain anticoagulants and hemolyzers and which neutralize the fibrinogen, thrombin, $\mathrm{Ca}+$ ions and vitamin $\mathrm{K}$ properties from the body.
\end{abstract}

\section{Introduction}

According to data from the bibliographic references the parasitic agents can directly influence the host's biochemical reactions, which represent practical and theoretical interest, because they determine the consequences of their interaction with the host, they disrupt metabolism, increasing the blood serum ferments activity, it's changing the proteinogram, immunogram, plasma hemostasis indices [1-4, 9-12, 20-22].

The evaluation of the disease, caused by the pathogenic action of the larvae in the migration phase, predominates the cellular defense factor. The hemostasis indices show about the organism's protective reaction that happens in stopping the hemorrhages. An optimal physiological blood clotting function maintaining is essential. The blood clotting deficiencies have a major impact on its intravascular fluidity. Excessive coagulation can lead to a blood vessel occlusion of vital importance, and the deficient one can cause a hemorrhagic condition, very difficult to fight [5-8, 13-19].

Also, it is known that in order to be developed effective measures in stabilizing hemostasis indices it is necessary to study their disorders level in mono- and polyparasite infestations and after that, can be taken measures for their normalization [5-8].

\section{Materials and methods}

The parasitological researches were carried out in the laboratory of Parasitology and Helminthology of the Institute of Zoology on 82 biological samples, collected during 2019 year from wild boars, raised at hunting from the "Pădurea Domnească" Nature Reserve forest ecosystem.

In the order to achieve the proposed objectives, were used coproovoscopic methods (Fulleborn, Darling), coprolarvoscopic methods (Popov, Baermann) and successive washing meth- 
od. The invasion's intensity with nematodes was established in $5 \mathrm{~g}$ of fetuses, and the oocysts of Eimeria spp., eggs of Fasciola hepatica, Dicrocoelium lanceolatum, etc., in 10 visual microscopic fields $(10 \mathrm{x} 40)$.

The mono- and polyinvasions impact on some morpho-functional indices in wild boars was identified by determining hematological indices, proteinogram indices and by plasma hemostasis indices in the reference laboratories.

\section{Results and discussion}

A special section of the investigations was to establish the impact of parasitic agents on the host - body to wild boars, through the analysis prism of hematological and biochemical indices. The collection of blood samples in order to establish some hematological and biochemical indices, have been taken from wild boars with different levels of infestation from various natural and anthropogenic biotopes of the Republic of Moldova.

The main objective of the investigations was to evaluate the consequences of mono- and polyparasitosis on the physiological status of wild boars. In order to achieve this objective, was initially studied the parasitofauna in wild boars, after which were selected 20 specimens and distributed in 4 groups with 5 wild boars in each lot: the I group - uninfested, the II group - spontaneously infested with Strongyloides papillosus, the III group - spontaneously infested with Dicrocoelium lanceolatum and the IV group - spontaneously polyinfested with Dicrocoelium lanceolatum, Strongyloides papillosus, Metastrongylus elongatus și Eimeria debliecki.

Determination of hematological indices (hemoglobin, erythrocytes, leukocytes, hematocrit, prothrombin, thrombosis time, erythrocyte sedimentation rate (ESR)) was performed at uninfested, mono- and polyparasitized wild boars (tab. 1).

Table 1. Mono- and polyinvasions impact on hematological indices in wild boars

\begin{tabular}{|c|c|c|c|c|c|c|c|}
\hline Groups & $\begin{array}{c}\text { Hb } \\
\text { (g/100ml } \\
\text { sânge) }\end{array}$ & $\begin{array}{c}\text { Erytrocytes, } \\
\mathbf{1 0}^{\mathbf{6}} \mathbf{m m}^{\mathbf{3}}\end{array}$ & $\begin{array}{c}\text { Leukocytes, } \\
\text { thousand / } \\
\mathbf{m m}^{\mathbf{3}}\end{array}$ & $\begin{array}{c}\text { Hematocrit } \\
\mathbf{( \% )}\end{array}$ & $\begin{array}{c}\text { Prothrombin } \\
\mathbf{\%}\end{array}$ & $\begin{array}{c}\text { Throm- } \\
\text { bosis time } \\
\text { (sec.) }\end{array}$ & $\begin{array}{c}\text { ESR } \\
\text { (ml/sec) }\end{array}$ \\
\hline I & $13,0 \pm 1,5$ & $7,2 \pm 0,6$ & $11,2 \pm \mathbf{1 , 2}$ & $41,5 \pm 3,6$ & $86,7 \pm 4,2$ & $42,2 \pm 2,3$ & $0,8 \pm 0,14$ \\
\hline II & $8,0 \pm 0,4$ & $5,5 \pm 0,4$ & $13,8 \pm \mathbf{1 , 6}$ & $32,2 \pm 3,2$ & $85,3 \pm 3,5$ & $36,6 \pm 1,8$ & $0,5 \pm 0,12$ \\
\hline III & $9,0 \pm 0,7$ & $6,5 \pm 0,7$ & $13,5 \pm \mathbf{1 , 4}$ & $35,5 \pm 2,5$ & $85,7 \pm 3,6$ & $34,5 \pm 1,3$ & $0,6 \pm 0,11$ \\
\hline IV & $7,4 \pm 0,5$ & $4,2 \pm 0,3$ & $14,4 \pm \mathbf{2 , 5}$ & $28,6 \pm 2,0$ & $84,2 \pm 3,3$ & $32,4 \pm 1,1$ & $0,5 \pm 0,10$ \\
\hline
\end{tabular}

In the result of the hematological indices investigation in mono- and polyparasitic uninfested wild boars, it was established that both the hemoglobin content indices, hematocrit, erythrocytes number, thrombosis time and ESR (erythrocyte sedimentation rate) vary and are higher at the I group with uninfested wild boars, compared to mono- and polyparasitic ones. The leukocyte content, being opposite, decreased in the I group - uninfested, comparative to its values at the II group - spontaneously infested with Strongyloides papillosus, the III group - spontaneously infested with Dicrocoelium lanceolatum and the IV group - spontaneously infested with Dicrocoelium lanceolatum, Strongyloides papillosus, Metastrongylus elongatus și 
Eimeria debliecki. Therefore, the index of hemoglobin content is more increased in the I group with uninfested wild boars, by $38,5 \%(\mathrm{P}>0,05)$, comparative to the II group - spontaneously infested with Strongyloides papillosus, by 30,8\% (P>0,05 ) comparative to the III group - spontaneously infested with Dicrocoelium lanceolatum and by $43,0 \%(\mathrm{P}>0,05)$ comparative to the IV group - wild boars spontaneously infested with Dicrocoelium lanceolatum, Strongyloides papillosus, Metastrongylus elongatus și Eimeria debliecki. The erythrocytes number also varies from group to group and being in the I group by $23,6 \%(\mathrm{P}>0,05)$ higher comparative to the II group, by $9.7 \%(\mathrm{P}>0,05)$, comparative to the III group and by $41,7 \%(\mathrm{P}>0,05)$, comparative to the IV group.The values of hematocrit and ESR indices are also higher in the I group by $22,4 \%$ ( $\mathrm{P}>0,05)$, comparative to the II group, by $14,5 \%(\mathrm{P}>0,05)$, comparative to the III group and by $31,0 \%(\mathrm{P}>0,05)$, comparative to the IV group for hematocrit content, and respectively higher in the I group by $37,5 \%(\mathrm{P}>0,05)$, comparative to the II and the IV group, and by $25,0 \%(\mathrm{P}>$ 0,05), comparative to the III group for ESR.Thrombosis time indices, was highlighted higher for the I group of uninfested wild boars by $15,9 \%$, comparative to the II and the III groups with monoparasitized wild boars (Strongyloides papillosus, Dicrocoelium lanceolatum) and by $23,3 \%(\mathrm{P}>0,05)$ comparative to the IV group with polyparasitized wild boars (Dicrocoelium lanceolatum, Strongyloides papillosus, Metastrongylus elongatus și Eimeria debliecki).

The leukocyte content shown in wild boar groups was on average lower in the I group, by $17,7 \%(\mathrm{P}>0,05)$, comparative to the II and the III groups and by $22,3 \%(\mathrm{P}>0,05)$, comparative with the IV lot. Also, it was studied the impact of monoinvasions (Strongyloides papillosus, Dicrocoelium lanceolatum) and polyinvasions (Dicrocoelium lanceolatum, Strongyloides papillosus, Metastrongylus elongatus și Eimeria debliecki) on the lymphocyte indices in wild boars (tab. 2).

Table 2. Mono- and polyinvasions impact on leukogram in wild boars

\begin{tabular}{|c|c|c|c|c|c|c|c|c|c|}
\hline \multirow{3}{*}{ Groups } & \multirow{3}{*}{$\begin{array}{c}\text { Leuko- } \\
\text { cytes } \\
\text { (thousand } \\
/ \mathbf{m m}^{3} \text { ) }\end{array}$} & \multirow{3}{*}{$\begin{array}{c}\text { Throm- } \\
\text { bocytes } \\
(\mathbf{m i i} / \\
\left.\text { mm }^{3}\right)\end{array}$} & \multicolumn{7}{|c|}{ Leukocyte formula (\%) } \\
\hline & & & \multirow{2}{*}{$\begin{array}{l}\text { Baso- } \\
\text { phils }\end{array}$} & \multirow{2}{*}{$\begin{array}{c}\text { Eosino- } \\
\text { phils }\end{array}$} & \multicolumn{3}{|c|}{ Neutrophil } & \multirow{2}{*}{$\begin{array}{c}\text { Lym- } \\
\text { phocytes }\end{array}$} & \multirow{2}{*}{$\begin{array}{c}\text { Mono- } \\
\text { cytes }\end{array}$} \\
\hline & & & & & Young & Stick & $\begin{array}{c}\text { Seg- } \\
\text { mented }\end{array}$ & & \\
\hline I & $11,2 \pm \mathbf{1 , 2}$ & $284 \pm \mathbf{1 0 , 4}$ & $0,5 \pm \mathbf{0 0 , 6}$ & & $1,6 \pm$ & $2,5 \pm 1$ & $40,6 \pm \mathbf{5 , 3}$ & 2 & 34 \\
\hline II & $13,8 \pm \mathbf{1 , 6}$ & $272 \pm \mathbf{1 2 , 0}$ & $0,4 \pm \mathbf{0 0 , 4}$ & 4,5 & 2, & 3 & $42,4 \pm \mathbf{5 , 6}$ & $41,7 \pm 4,4$ & $5,7 \pm \mathbf{0 , 6 2}$ \\
\hline III & $13,5 \pm \mathbf{1 , 4}$ & $274 \pm \mathbf{1 2 , 3}$ & $0,4 \pm \mathbf{0 0 , 3}$ & $3,9 \pm \mathbf{0 , 2 8}$ & $2,8 \pm \mathbf{0 , 6}$ & $3,4 \pm \mathbf{0 , 3 2}$ & $45,8 \pm \mathbf{6 , 4}$ & $38,6 \pm \mathbf{3}, 7$ & $5,4 \pm \mathbf{0 , 7 6}$ \\
\hline IV & $14,4 \pm \mathbf{2 , 5}$ & $265 \pm \mathbf{1 2 , 6}$ & $0,2 \pm \mathbf{0 0 , 2}$ & $5,4 \pm \mathbf{0 , 2 6}$ & $3,7 \pm \mathbf{0 , 8}$ & $4,8 \pm \mathbf{0 , 3 8}$ & $45,4 \pm \mathbf{5 , 8}$ & $35,5 \pm \mathbf{3}, \mathbf{8}$ & $6,0 \pm \mathbf{0 , 7 4}$ \\
\hline
\end{tabular}

In the analysis result of the leukocyte formula in wild boars, was found a decrease of the eosinophils number from the I group - uninfested by $29,0 \%$ (P>0,05), comparative to the II group - spontaneously infested with Strongyloides papillosus, by 18,0\% (P > 0,05), comparative to the III group - spontaneously infested with Dicrocoelium lanceolatum and respectively with $40,8 \%(\mathrm{P}>0,05)$ decreased, comparative to the IV group, with polyparasitized wild boars (Dicrocoelium lanceolatum, Strongyloides papillosus, Metastrongylus elongatus and Eimeria debliecki).Depending on the parasitic species and the level of wild boar infestation, there are variations in the leukocyte formula of the young neutrophils content, which are also decreased 
in the I group - uninfested wild boars by $27,3 \%(\mathrm{P}>0,05)$, comparative to those from the II group, by $42,9 \%(\mathrm{P}>0,05)$, comparative to those from the III group and by $56,8 \%(\mathrm{P}>0,05)$, comparative to the IV group.The lymphocyte indices analysis shows variations in the lymphocyte content, which is higher in the I group with uninfested wild boars by $13,0 \%(\mathrm{P}>0,05)$, comparative to those from the II group, by $19,5 \%$ ( $\mathrm{P}>0,05)$, comparative to those from the III group and by $25,9 \%(\mathrm{P}>0,05)$, comparative to polyparasitized wild boars from the IV group.

In the study's result of the impact of mono- and polyinvasions on lymphocyte indices in wild boars, it was possible to highlight the fact that both their invasion with Strongyloides papillosus from the II group, and with Dicrocoelium lanceolatum from the III group, and polyinvasion with Dicrocoelium lanceolatum, Strongyloides papillosus, Metastrong elongatus and Eimeria debliecki, ultimately, leads to the substances release with immunotoxic action on B, T and Th lymphocytes, affecting them morphofunctionally and increasing the amount of null and Ts lymphocytes (tab. 3).

In the study's result of the mono- and polyinvasions impact, on the proteinogram's indices in wild boars, was established in them the content of total proteins, albumins and globulins (tab. 4).

Table 3. Mono- and polyinvasions impact on lymphocyte indices in wild boars

\begin{tabular}{|c|c|c|c|c|c|c|}
\hline \multirow{2}{*}{ Groups } & \multirow{2}{*}{$\begin{array}{c}\text { Total lym- } \\
\text { phocytes \% }\end{array}$} & $\mathbf{B}$ & $\mathbf{T}$ & null & $\mathbf{T h}$ & Ts \\
\cline { 3 - 7 } & & $\mathbf{\%}$ & $\mathbf{\%}$ & $\mathbf{\%}$ & $\mathbf{\%}$ & $\mathbf{\%}$ \\
\hline I & $47,9 \pm \mathbf{4 , 2}$ & $17,4 \pm 2,4$ & $52,0 \pm 2,6$ & $22,1 \pm 3,2$ & $22,1 \pm 1,1$ & $18,3 \pm 1,2$ \\
\hline II & $41,7 \pm \mathbf{4 , 4}$ & $16,2 \pm 1,3$ & $28,1 \pm 1,7$ & $47,4 \pm 3,4$ & $12,0 \pm 1,1$ & $27,3 \pm 1,4$ \\
\hline III & $38,6 \pm \mathbf{3 , 7}$ & $12,2 \pm 1,5$ & $21,4 \pm 1,5$ & $54,2 \pm 2,3$ & $9,8 \pm 2,2$ & $25,3 \pm 2,4$ \\
\hline IV & $35,5 \pm \mathbf{3 , 8}$ & $10,2 \pm 1,5$ & $20,2 \pm 1,4$ & $58,3 \pm 2,6$ & $10,2 \pm 2,4$ & $28,4 \pm 3,6$ \\
\hline
\end{tabular}

Table 4. Mono- and polyinvasions impact on proteinogram indices in wild boars

\begin{tabular}{|c|c|c|c|c|c|c|}
\hline \multirow{3}{*}{ Groups } & \multirow{3}{*}{$\begin{array}{c}\text { Total } \\
\text { protein, } \\
\mathrm{g} / 100 \mathrm{ml}\end{array}$} & \multirow{3}{*}{$\begin{array}{c}\text { Albumins, } \\
\%\end{array}$} & \multicolumn{4}{|c|}{ Globulins } \\
\hline & & & $\alpha_{1}$ & $\alpha$, & $\beta$ & $\gamma$ \\
\hline & & & $\%$ & $\%$ & $\%$ & $\%$ \\
\hline I & $7,7 \pm 1,16$ & $35,4 \pm 1,62$ & $8,0 \pm 0,34$ & $9,5 \pm 0,52$ & $11,9 \pm 0,45$ & $27,8 \pm 1,45$ \\
\hline II & $5,1 \pm 1,12$ & $30,2 \pm 1,12$ & $6,4 \pm 0,44$ & $10,4 \pm 0,34$ & $13,5 \pm 0,82$ & $33,3 \pm 0,78$ \\
\hline III & $6,2 \pm 0,99$ & $32,8 \pm 0,77$ & $6,9 \pm 0,43$ & $11,6 \pm 0,37$ & $14,6 \pm 0,54$ & $32,2 \pm 1,13$ \\
\hline IV & $4,8 \pm 0,86$ & $27,6 \pm 0,86$ & $5,4 \pm 0,32$ & $12,4 \pm 0,34$ & $15,8 \pm 0,32$ & $36,4 \pm 1,62$ \\
\hline
\end{tabular}

In the wild boars from the II group, infested spontaneously with Strongyloides papillosus, was observed a total protein's content of 33,8\% (P>0,05), in those from the III group - by $19,5 \%(\mathrm{P}<0,05)$, and in those from the IV group - by $37,7 \%(\mathrm{P}<0,05)$ decreased, comparative to the I group. The albumin decreases by $14,7 \%(\mathrm{P}<0,01)$ in the II group, by $7,4 \%(\mathrm{P}<0,01)$ in the III group and by $22,0 \%(\mathrm{P}<0,01)$ in the IV group, comparative to the I group, uninfested. 
The $\alpha 1$ globulins, decreased by $20,0 \%(\mathrm{P}<0,05)$ in the II group, in the III group - by $13,8 \%$, and in the IV group - by $32,5 \%$, comparative to the I group. The globulins $\alpha 2$ level from the II group was with $8,7 \%(\mathrm{P}>0,05)$, in the III group with $18,1 \%(\mathrm{P}>0,05)$, and in the IV group with $23,4 \%(\mathrm{P}>0,05))$ increased, comparative to the I group. $\beta$ globulins in the II group was by $11,9 \%(\mathrm{P}>0,05)$, inthe III group by $18,5 \%(\mathrm{P}>0,05)$, and in the IV group - by $24,7 \%(\mathrm{P}>$ $0,05)$, also increased, comparative to the I group, and the globulin $\gamma$ level, in the II group was by $16,5 \%(\mathrm{P}>0,05)$, in the III group by $13,7 \%(\mathrm{P}>0,05)$, and in the IV group - with $23,6 \%(\mathrm{P}>$ $0,05)$ higher at infested groups, comparative to the I group, uninfested.

The obtained results indicate that the infestation with Strongyloides papillosus causes a proteinogram indices decrease, characteristic for the type I electrophoregram changes, specific to the acute inflammatory processes, due to the mechanical and spoiling action of the rhabditoid larvae, which circulate in the pathogenic microflora in the host organism. Infestation with Dicrocoelium lanceolatum leads to the proteinogram's index change and causes respective changes, wich expressed the VIII electrophoregram type, specific for the hepatobiliary symptomatic complex, due to the toxic action, mechanical and spoliating action of dichroceles from the liver's bile ducts.In the study's result of the mono- and polyinvasions impact on the plasma hemostasis indices in wild boars, it was established that the prothrombin index's level (PI) in animals from the II group was lower by $16,4 \%(\mathrm{P}>0,05)$, in those from the III group by $14,2 \%$ $(\mathrm{P}>0,05)$ and in those from the IV group by $18,2 \%(\mathrm{P}>0,05)$, comparative to those from the I group. The activated recalcification time (TRA), in wild boars from the II group, has increased compararative to the I group by $16,8 \%(\mathrm{P}>0,05)$, from the III group by $9,5 \%(\mathrm{P}>0,05)$ and from the IV group by $18,5 \%$ ( $\mathrm{P}>0,05)$. The activated partial thromboplastin time (aPTT) also increased in wild boars from the II group by $18,7 \%(\mathrm{P}>0,5)$, in the III group by $11,4 \%(\mathrm{P}>$ $0,05)$ and in the IV group with $19,1 \%(\mathrm{P}>0,05)$, comparative to those from the I group. Thrombin time (TT) is in decreasing at infested groups, by $21,3 \%(\mathrm{P}>0,05)$ in the II group, with $14,9 \%(\mathrm{P}<0,05)$ in the III group and with $24,6 \%(\mathrm{P}<0,05)$ in the IV group, comparative to the I group - uninfested wild boars. The fibrinogen content from the I group with uninfested wild boars is higher with $21,2 \%$ than in the II group and with $9,7 \%(\mathrm{P}>0,05)$ than in the III group with monoinfested wild boars, and by $36.6 \%(\mathrm{P}>0,05)$ than in the IV group with polyinfested wild boars. Ca2+ content, is also decreased by $35,5 \%(\mathrm{P}>0,05)$ in the II group, in the III group by $23,5 \%(\mathrm{P}>0,05)$ and in the IV group by $44,2 \%(\mathrm{P}>0,05)$, comparative to the I lot. (tab. 5$)$.

Table 5. Mono- and polyinvasions impact on the plasma hemostasis indices in wild boars

\begin{tabular}{|c|c|c|c|c|c|c|}
\hline Groups & PI,\% & TRA,seconds & aPTT,seconds & TT,seconds & Fibrinogen,g/l & Ca $^{2+}, \mathbf{m m o l} / \mathbf{l}$ \\
\hline I & $98,3 \pm 3,35$ & $65,4 \pm 2,4$ & $46,6 \pm 1,3$ & $30,4 \pm 1,2$ & $5,2 \pm 0,21$ & $3,4 \pm 0,18$ \\
\hline II & $82,2 \pm 3,21$ & $78,6 \pm 2,6$ & $57,3 \pm 1,4$ & $38,6 \pm 1,4$ & $4,1 \pm 0,32$ & $2,2 \pm 0,12$ \\
\hline III & $84,4 \pm 2,79$ & $72,2 \pm 2,1$ & $52,6 \pm 2,1$ & $35,7 \pm 1,3$ & $4,7 \pm 0,33$ & $2,6 \pm 0,24$ \\
\hline IV & $80,4 \pm 2,21$ & $80,2 \pm 2,6$ & $57,6 \pm 2,6$ & $40,3 \pm 0,30$ & $3,3 \pm 0,18$ & $1,9 \pm 0,12$ \\
\hline
\end{tabular}


The obtained results indicate that, both in boars infested with S. papillosus from the I group and in those infested with $D$. lanceolatum from the II group, indices was established a hemostatic decrease, and their maximum decrease is highlighted in the IV group with polyinfested wild boars with Dicrocoelium lanceolatum, Strongyloides papillosus, Metastrongylus elongatus and Eimeria debliecki. This decrease is due to exotoxins eliminated by parasites, which contain anticoagulant and hemolyzer substances, and which neutralize the fibrinogen, thrombin, $\mathrm{Ca}+$ ions and vitamin $\mathrm{K}$ properties.

The studies were carried out within the research project no. 20.80009.7007.12.

\section{Bibliography}

1. Borman A., Wrona D., Kamyczek M..-Prolonged changes in lymphocyte population under repeated immobilization. I.Halothane-susceptible pigs. Anim. Sci., Rap. and Repts., 1992, No 10, p. 35-45.

2. Doğanay A. Impact of the animal parasitic diseases. Vet. Hekim. Dern. Derg., 1993, V.64, No2, p. 52-59.

3. Erhan D. Tratat de parazitoze asociate ale animalelor domestice. Chişinău, Î.S. Firma Editorial-Poligrafică „Tipografia Centrală”. 2020, 1038 p.

4. Olinescu A., Andrieş A. Tehnici imunologice // Chişinău, "Ştiinţa". 1994, 316 p.

5. Olteanu G., Panaitescu D., Gherman I. ș.a. Probleme ale parazitozoono- zelor spre sfârşit de mileniu în România. Revista Română de Parazitologie. 1995, Vol. V, Nr. 1, p. 1-11.

6. Olteanu G., Panaitescu D., Gherman I. şi colab. Poliparazitismul la om, animale, plante și mediu. Ed. Ceres. București, 2001, 818 p.

7. Olteanu G., Panaitescu D., Gherman I., ș.a. Probleme ale parazitozoonozelor spre sfârşit de mileniu în România. Revista Română de Parazitologie. 1995, Vol. V, Nr. 2, p. 1-19.

8. Part V. Metal-metal interaction in biological systems. Water, Air, and Soil Pollut., 1997, V.93, no 1-3, p. 213-223.

9. Curcă D. Conţinutul de acid ascorbic; manifestările cantitative şi calitative ale colagenului la animale în unele zoonoze // Revista Română de parazitologie. 1992, V.2, nr. 2, p. 66-67.

10. Thienel I., Zyhs Z. The experimental stress modeling on the young pigs. Wiad. Parazitol., 1981, V.8, no 2, p. 37.

11. Алешин Б.В. Эндокринная система и гемостаз. В кн.: Гомеостаз (п/р П.Д.Горизонтова).2-ое изд.-М.: Медицина, 1981, с. 77-113.

12. Балаян Д.Е. Влияние гельминтозов на содержание микроелементов (меди, молибдена, железа) в тканях и органах овец. Зоол. Сб. АН Арм. ССР, Инст.Зоол., 1982, Т.18, с. 46-56.

13. Баньковская И.Б. Селекция на мясность и качество свинины. Тез. Докл. На IV междунар. Конф. Науч. Произв. Аспекты Развития Отрасли Свиновод.,-Лесные Поляны, 1997, с. 60.

14. Гаджиев Я.Г., Гораев В.Х. Роль микроелементов в развитии и значение их применения при гельминтозах. Тез. Докл. ІХ Съезда ВОГ, Тбилиси, 3-5 апреля 1986, с. 6-37.

15. Германов В.А., Пиксанов О.Н. Эритроциты, тромбоциты, лейкоциты. Куйбышевское книжное издат.-во. 1966, 164 с.

16. Горизонтов П.Д., Федотова М.И., Егорова Л.Н. Реакция системы крови адреналэктомированных мышей на стрессорное воздействие. Пат. Физиол., 1981, №5, c.36-39.

17. Горизонтов П.Д., Белоусова О.И., Федотова М.И. Стресс и система крови.-М.:Медицина, $1983,318 \mathrm{c}$.

18. Гурьянов А.М., Петуненков В.А., Калачина В.А. Микроелементы и их взаимосвязь в организме свиней. Морд. Гос.унив., Аграр. Инст.- Саранск. 1997, с. 190-194. 
19. Гурьянов А.М., Кокорев В.А., Петуненков В.А., Слушкин М.В. Оптимизация уровня и соотношения микроелементов в рационах свиней разного возраста. Морд. Гос.унив., Аграр. Инст.- Саранск. 1997, с. 194-196.

20. Ковак Л., Сидор В. Влияние стрессов на биохимические показатели крови у свиней . М.: Агропромиздат, 1982, с. 317.

21. Мозалене Э.Э., Медзявичюс А.К. Влияние витамина С на динамику содержания церулоплазмина в сыворотке крови поросят при экспериментальном трихоцефалезе. // Тр. АН Лит.ССР. , 1989, №1, с. 86-91.

22. Мясцова Г.Я. Динамика лизоцима сыворотки крови при моно- и смешанной инвазиях свиней нематодами. Актуальные вопросы профилактики и борьбы с болезнями c/x животных.-Тез. Докл., 1983, с. 81-82. 